\title{
HUMAN SPERM MOTILITY, VIABILITY, AND MORPHOLOGY DECREASE AFTER CRYOPRESERVATION
}

\author{
Ninik Darsini ${ }^{1}$, Berliana Hamidah ${ }^{1,2}$, Seso Sulijaya Suyono ${ }^{3}$, Faisal Yusuf Ashari ${ }^{1}$, R Haryanto Aswin' ${ }^{1}$, Rina \\ Yudiwati ${ }^{1}$ \\ ${ }^{1}$ Department of Medical Biology, ${ }^{2}$ Reproductive Health Master Program, ${ }^{3}$ Andrology Program, Faculty of Medicine, \\ Universitas Airlangga, Dr Soetomo Hospital, Surabaya, Indonesia
}

\begin{abstract}
The aim of this study was to analyze human sperm motility, viability, and morphology before and after cryopreservation. This true laboratory experimental study had pre and post randomized one group design. The study was conducted at the Embryology, Andrology, and Genetics Laboratory, Department of Medical Biology, Faculty of Medicine, Universitas Airlangga from August to November 2017. The eighteen samples of fresh semen were collected from male volunteers who agreed and signed the informed consent of the study. Samples were analyzed their motility, viability, and morphology before and after cryopreservation. Results of this study indicated differentiation between motility before and after cryopreservation. Cryopreservation process decreased progressive motility $(42.22 \pm 9.46 \% ; 17.83 \pm 6.24 \% ; p<0.0001)$ and increased the number of immotile spermatozoa $(35.44 \pm$ $10.15 \% ; 60.11 \pm 12.53 \% ; p<0.0001)$. Cryopreservation also decreased human sperm viability $(73.78 \pm 8.91 \% ; 40.83 \pm 12.89 \%$; $p<0.0001)$ and morphology (10.94 $\pm 4.96 \% ; 7.39 \pm 3.90 \% ; p<0.0001)$. Cryopreservation of human spermatozoa caused the decreased of motility, viability, and morphology.
\end{abstract}

Keywords: Cryopreservation; sperm morphology; sperm motility; sperm viability

\section{ABSTRAK}

Penelitian ini bertujuan untuk menganalisis motilitas, viabilitas, dan morfologi spermatozoa manusia sebelum dan sesudah kriopreservasi. Penelitian eksperimental laboratorium murni ini memiliki desain penelitian pre and post randomized one group design serta dilakukan di Laboratorium Embriologi, Andrologi, dan Genetika Departemen Biologi Kedokteran Fakultas Kedokteran Universitas Airlangga pada Agustus hingga November 2017. Sebanyak delapan belas sampel semen segar didapatkan dari sukarelawan yang telah menyetujui dan menandatanagani informed consent. Kedelapan belas sampel tersebut dilakukan analisis semen berupa pemeriksaan motilitas, viabilitas, serta morfologi sebelum dan sesudah kriopreservasi. Hasil penelitian ini menunjukkan adanya perbedaan motilitas sebelum dan sesudah kriopreservasi. Proses kriopreservasi menyebabkan penurunan motilitas progresif $(42.22 \pm 9.46 \% ; 17.83 \pm 6.24 \% ; p<0.0001)$ dan peningkatan jumlah spermatozoa immotil $(35.44 \pm 10.15 \%$; $60.11 \pm 12.53 \% ; p<0.0001)$. Kriopreservasi juga menyebabkan penurunan viabilitas $(73.78 \pm 8.91 \% ; 40.83 \pm 12.89 \% ; p<0.0001)$ dan morfologi $(10.94 \pm 4.96 \% ; 7.39 \pm 3.90 \% ; p<0.0001)$ spermatozoa manusia. Kriopreservasi spermatozoa manusia dapat menyebabkan penurunan motilitas, viabilitas, dan morfologi.

Kata kunci: Kriopreservasi; morfologi spermatozoa; motilitas spermatozoa; viabilitas spermatozoa

Correspondence: Ninik Darsini, Department of Medical Biology, Faculty of Medicine, Universitas Airlangga, Jl. Mayjen. Prof. Dr. Moestopo 47, Surabaya, Indonesia. Phone: (031) 5020251-1137. E-mail: ninik-d@ fk.unair.ac.id

pISSN:2355-8393 • eISSN: 2599-056x • doi: http://dx.doi.org/10.20473/fmi.v55i1.12564

• Fol Med Indones. 2019;55:198-201• Received 1 Aug $2018 \bullet$ Accepted 25 Jul 2019

- Open access under CC-BY-NC-SA license • Available at https://e-journal.unair.ac.id/FMI/

\section{INTRODUCTION}

Cryopreservation has become an important part of the development of assisted reproduction technology (ART). Nowadays, cryopreservation can be performed on spermatozoa, oocytes, and embryos at various stages of embryonic development (Di Santo et al. 2012). Cryopreservation of human spermatozoa, although it has a detrimental effect on the spermatozoa quality, remains an option in the application of ART, for example in intra uterine insemination (IUI), in vitro fertilization (IVF), and intracytoplasmic sperm injection (ICSI) (Moce et al. 2016).

Cryopreservation indications include sperm storage of severe oligoasthenoteratozoospermia (OAT) to prevent the possibility of decreased quality and number of spermatozoa to optimizing the ART results (Di Santo et 
al. 2012), male fertility preservation before chemo or radiotherapy (McLaughlin and Pacey 2009, Di Santo et al. 2012), and sperm storage from epididymal or testicular (Di Santo et al. 2012, Boitrelle et al. 2012).

Sperm cryopreservation can cause damage to spermatozoa which results in decreased sperm motility and viability (McLaughlin and Pacey 2009). A decrease in the motility and viability may lead to a decline in fertilization ability (Zribi et al. 2010). The ice crystals formation of sperm cryopreservation cause the buildup of electrolytes and other solutes in cells that damage the sperm intracellular (Yeste 2016). This intracellular damage is difficult to detect but causes damage the sperm function.

The aim of this study is to analyze sperm quality factors that lead to the sperm ability to fertilize oocyte before and after cryopreservation. That factors are sperm motility, viability, and morphology analized using semen analysis (WHO 2010).

\section{MATERIALS AND METHODS}

This true laboratory experimental study had pre and post randomized one group design. The study was conducted at the Embryology, Andrology, and Genetics Laboratory, Department of Medical Biology, Faculty of Medicine, Universitas Airlangga from August to November 2017. The study was agreed by local ethical commision (Komite Etik Penelitian Kesehatan Fakultas Kedokteran Universitas Airlangga) and shown by ethical clearance certificate.

Eighteen samples of fresh semen were collected from male volunteers that agreed and signed the informed consent of the study. Samples taken using WHO (2010) standard and completed the study criterias, semen volume $>2 \mathrm{ml}$ and sperm concentration $>5 \mathrm{x}$ 106/ml.

The samples were analyzed their motility, viability, and morphology right after liquefaction. Sperm motility, morphology, and viability analized using WHO (2010) protocol. All of this examination took two times, before and after freezed-thawed process of cryopreservation.

Sperm cryopreservation with rapid freezing technique used $0.5 \mathrm{ml}$ straw and mixed of $1: 1$ sample and cryoprotectant (SpermFreezeTM, Vitrolife Inc.). The mixed speciment intra straw then steamed $3 \mathrm{~cm}$ apart from the liquid nitrogen for 30 minutes and storaged in liquid nitrogen (-1960C) tank for 24 hours. The straws then thawed in waterbath $(370 \mathrm{C})$ for 30 seconds and placed in room temperature for 20 minutes before the second sperm quality examinations.
Data analysis was compare the sperm motility, viability, and morphology before and after sperm cryopreservation used SPSS 21 statistic software and was described as significant different if $\mathrm{p}$ value $<\mathrm{a}$ $(\mathrm{a}=5 \%)$. Normal distribution analized using One Sample Kolmogorov Smirnov test and the different between before and after cryopreservation analyzed using Paired T-test.

\section{RESULTS}

The range of eighteen sperm concentration was 9.04 $122 \times 106 / \mathrm{ml}$ with the average was $40.66 \pm 25.34 \mathrm{x}$ $106 / \mathrm{ml}$. All the datas showed normal distribution analized using One Sample Kolmogorov Smirnov test. The results of sperm progressive motility showed significantly decreased after cryopreservation, the sperm immotile number showed significantly increased, while the sperm non progressive motility after cryopreservation was decreased but not significant (Table 1). Whereas, The paired T-test results showed that the sperm viability and morphology before and after cryopreservation was significantly different (Table 2).

\section{DISCUSSION}

The most influential factor of the sperm motility is the availability of energy generated by disassembling adenosine triphosphate (ATP) into adenosine diphosphate (ADP), thus driving microtubule doublets in axonema (Cooper and Yeung 2010). Mitochondria are located in the midpiece between the membrane and nine spindle threads, having the function of providing the energy needed for sperm motility. The largest energy used by spermatozoa is the ATP molecules that are made in cytoplasm by glycolysis or phosphorylative oxidation in mitochondria. The ATP then will be transferred to spindles or microtubules to move the sperm tail (Di Santo 2012).

Sperm progressive motility before and after cryopreservation showed statistically significant decrease outcomes, accompanied by a significant increase in immotile numbers. This change may be explained that in the cryopreservation process, sperm plasma and mitochondria membrane are very susceptible to be disturbed. Changes in fluidity of the mitochondrial membrane potentially produce and release reactive oxygen species (ROS) (Agarwal et al. 2014), indirectly, thus significantly decrease sperm motility (Di Santo 2012). 
Table 1 . Human sperm motility before and after cryopreservation

\begin{tabular}{lccc}
\hline Type of sperm motility & $\begin{array}{c}\text { Before cryopreservation } \\
(\text { mean } \pm \text { SD) }\end{array}$ & $\begin{array}{c}\text { After cryopreservation } \\
(\text { mean } \pm \text { SD) }\end{array}$ & P value \\
\hline Progressive & $42.22 \pm 9.46 \%$ & $17.83 \pm 6.24 \%$ & $<0.0001$ \\
Non progressive & $22.33 \pm 9.17 \%$ & $22.06 \pm 7.91 \%$ & 0.929 \\
Immotile & $35.44 \pm 10.15 \%$ & $60.11 \pm 12.53 \%$ & $<0.0001$ \\
\hline Sperm motility was analyzed using WHO (2010) protocol & &
\end{tabular}

Table 2. Human sperm viability and morphology before and after cryopreservation

\begin{tabular}{lccc}
\hline Sperm parameters & $\begin{array}{c}\text { Before cryopreservation } \\
(\text { mean } \pm \text { SD) }\end{array}$ & $\begin{array}{c}\text { After cryopreservation } \\
(\text { mean } \pm \text { SD) }\end{array}$ & P value \\
\hline Viability & $73.78 \pm 8.91 \%$ & $40.83 \pm 12.89 \%$ & $<0.0001$ \\
Morphology & $10.94 \pm 4.96 \%$ & $7.39 \pm 3.90 \%$ & $<0.0001$ \\
\hline Sperm viability and morphology were analyzed using WHO (2010) protocol
\end{tabular}

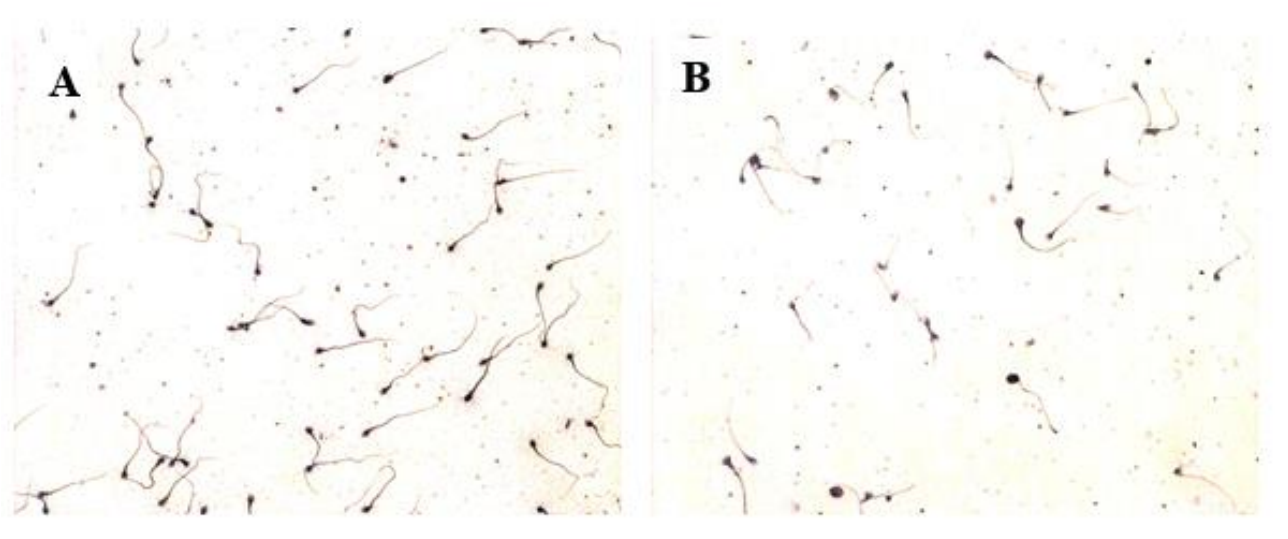

Fig. 1. Sperm morphology different between before (A) and after (B) cryopreservation

Sperm viability before and after cryopreservation showed statistically significant decreased. Cryopreservation produces ROS in spermatozoa (Agarwal et al. 2014) that can cause deviation of sperm structures such as disturbances in the plasma membrane. This change is associated with decreased motility, viability, and fertilization ability of spermatozoa (Boitrelle et al. 2012). Sperm plasma membran contains rich phospolipid and cholesterol that can modified by crypreservation process (Di Santo 2012). The death of spermatozoa after cryopreservation may be caused by cryoinjury. Cryoinjury can occured by the intracellular ice formation or electrolyte imbalance due to extracellular unfrozen fraction (Yeste 2016).

Sperm morphology after cryopreservation significantly decreased. The sperm morphological changes are also possible due to the cryopreservation process. This mechanism is related to osmotic stress and intracellular ice crystall formation (Yeste 2016). Morphological changes are also occured during rehydration and increasing temperature after thawing. Ice crystals during sperm cryopreservation cause structural and membrane integrity changes then form of spermatozoa morphological change.

The important factor that contribute to sperm survival during cryopreservation is cryoprotecting agent (CPA). CPA will act as protective agents for cell membranes and organelles in order to avoid damage to cell integrity during freezing and thawing process (Yeste 2016). Intracellular CPA use different osmotic pressure between intra and extracellular to enter the intracellular to provide cytoplasmic protection. Extracellular CPA cause intracellular dehydration due to different osmotic pressure without entering into cells. Commonly used as intracellular CPAs are glycerol (glycerin), dimethylsulfoxide (DMSO), ethylene glycol, 1,2 propanediol. Extracellular CPA which may be used are polyvinyl pyrrolidone (PVP), sugars (sucrose, glucose, rafinose), proteins and lipoproteins, egg yolks, blood serum, and milk (Hossain 2008). 
The sperm intracellular component can increase sperm survival. This is due to the amount of macromolecules dissolved in the spermatozoa cytosol is high so the amount of water is less (Di Santo et al. 2012). This condition resulting the sperm cytosolic viscosity becomes high and can serve as natural cryoprotectant which is not toxic. The sperm ability to maintain its viability in frozen storage also influenced by CPA.

\section{CONCLUSION}

This study conclude that there is different of sperm motility, viability, and morphology before and after cryopreservation. The cryopreservation process leads to a decrease in sperm progressive motility and elevated sperm immotiles. The cryopreservation process also leads to decreased sperm viability and morphology.

Furthermore, it is necessary for further studies about the sperm ability for fertilize oocyte and also the sperm genetic materials condition after cryopreservation.

\section{ACKNOWLEDGMENT}

Thanks to Faculty of Medicine, Universitas Airlangga, Surabaya which has provided funding this study through the Research and Community Development Unit (Unit Penelitian dan Pengabdian Masyarakat) Faculty of Medicine, Universitas Airlangga in 2017.

\section{REFERENCES}

Agarwal A, Durairajanayagam D, du Plessis SS (2014). Utility of antioxidants during assisted reproductive techniques: an evidence based review. Reproductive Biology and Endocrinology 12, 1-19

Boitrelle F, Albert M, Theillac C, Ferfouri F, Bergere M, Vialard F, Wainer R, Bailly M, Selva J (2012). Cryopreservation of human spermatozoa decreases the number of motile normal spermatozoa, induces nuclear vacuolization and chromatin decondensation. Journal of Andrology 33, 1371-1378

Cooper TG, Yeung CH (2010). Physiology of sperm maturation and fertilization. In: Nieschlag E, Behre HM, Nieschlag S (eds). Andrology, 3rd edition, Springer, 61-86

Di Santo M, Tarozzi N, Nadalini M, Borini A (2012). Human sperm cryopreservation: Update on technique, effect on DNA integrity, and implications for ART. Advances in Urology, 1-12

Hossain A (2008). Cryopreservation of male gametes. Infertility and Assisted Reproduction, Cambridge, Botroz and Juan Garcia, p 466-475

McLaughlin EA, Pacey AA (2009). Cryopreservation and storage of spermatozoa. In: Gardner DK, Weissman A, Howles CM, Shoham Z (eds). Text Book of Assisted Reproduction Technologies. 3rd Ed. Informa Healtcare, p 311-321

Moce E, Fajardo AJ, Graham JK (2016). Human sperm cryopreservation. European Medical Journal 1, 86-91.

WHO (2010). WHO Laboratory Manual for the Examination and Processing of Human Semen. 5th Ed. Geneva, WHO Press

Yeste M (2016). Sperm cryopreservation update: Cryodamage, markers, and factors affecting the sperm freezability in pigs. Theriogenology $85,47-64$

Zribi N, Chakroun NF, El Euch H, Gargouri J, Bahloul A, Keskes LA (2010). Effect of cryopreservation on human sperm deoxyribonucleic acid integrity. Fertility and Sterility 93, 159-166 